\title{
How Useful are the Main Existing Theories of Ethnic Conflict?
}

\author{
Dodeye Uduak Williams (PhD) \\ Department of Political Science, University of Calabar, Calabar - Nigeria
}

\section{Doi:10.5901/ajis.2015.v4n1p147}

\begin{abstract}
This paper explores the utility of these theories in terms of the extent to which they explain the phenomenon of ethnic conflict and provide a basis for meaningful intervention. It argues that given the multi-dimensional nature of ethnic conflicts, there is no single theory that is robust enough to explain the origin and dynamics of ethnic conflict and although each of these theories has significant contributions to understanding the phenomenon, they are all limited in their explanatory, predictive and prescriptive ability mainly as a result of their implicit bias regarding the origin of ethnic identity. It suggests that a framework that incorporates all the strengths of these major theories can explain how all the different factors, they highlight, interact to trigger ethnic conflict; and this will in turn produce balanced narratives that will drive more effective intervention policies and programs in specific contexts.
\end{abstract}

Keywords: Ethnicity, Ethnic Conflicts, Primordialism, Constructivism, Instrumentalist

\section{Introduction}

Ethnic conflict, a highly contested phenomenon, has been a part of international politics throughout history and is still a common form of contemporary armed conflict around the world (Nguyen, 2010). The causes of ethnic conflict are densely debated by scholars across disciplines but these arguments can be categorized into three major theories of ethnic conflict namely primordialism, instrumentalism and constructivism. Each of these theories have specific assumptions regarding the origin of ethnic identities, and following from this they reflect different causes of ethnic conflict. Ethnic conflict is defined in this paper as conflict where at least one group defines its goals exclusively in ethnic terms and in which the fault-line of confrontation is one of ethnic variation (Cordell and Wolf, 2010:4).

\section{Primordialism}

Primordialism argues that ethnic identity is ascriptive, in that membership is assigned at birth and thus difficult to change (Isajiw, 1993). It posits that ethnic ties are inherent in us as human beings and we have deep natural connections that connect us to some people and produce natural divisions with others whether based on race, religion, language or location (Geertz, 1973:250). Membership of ethnic groups is therefore fixed and passed down intact across generations (Chandra, 2012). Primordialism perceives an ethnic group as an objective entity (Perez and Hirschman, 2009) and ethnic identity for them is singular, timeless and fixed with distinct social boundaries (Poata-Smith, 2013). Ethnic differences are perceived as ancestral, deep and irreconcilable (Esteban et al., 2012) and as such ethnic conflict stems naturally and inevitably from 'ancient hatreds' between ethnic groups (Weir, 2012). Primordialism explains the fear of domination, expulsion or even extinction that lies at the base of most ethnic conflicts (Glazer, 1986:429) and reveals the attachment to beliefs that provoke a depth of emotion and sheer intensity that drive the violent atrocities committed in these conflicts. As Connor (1994) rightly observes, primordialism explains the passions that led to the massacre of Bengalis by Assamese or Punjabis or Sikhs in 1971 known as one of the worst genocides in history or the 1994 Rwandan genocide. The acts of rape (of men, women and children), genocide, hacking of limbs, mass displacement, torture, brutal murders (Bowman, 1994) and many other forms of unspeakable atrocities committed in conflicts like Yugoslavia, Rwanda, and Democratic Republic of Congo can best be described as emotionally driven behavior from feelings of fear, hatred and anxiety. The strength of this theory is also its weakness and the reason why it has been so widely discredited. It tends to emphasize the irrationality of ethnic violence (Turton, 1997:81) and leans towards an idea of genetically induced barbaric behavior (Campbell, 2007:363) projecting a picture of hopelessness and perceiving ethnic conflict as 'permanent and ineradicable' (Laitin and Sunny, 1999:153). Primordialism ignores the structural, economic and political processes within which these conflicts erupt (McKay, 2011) and implies that in ethnically heterogenous societies there will naturally and inevitably be 
violent ethnic conflicts but this is not a fact given that some societies like Botswana, an ethnically heterogenous country which, compared to many African countries, have peaceful ethnic relations (Holm and Molutsi, 1992). For instance, one of the explanations for the peaceful ethnic relations in the Botswana case is that it has a 'constitutionally grounded ethnic differentiation', which, though not perfect, has allowed for a 'near total absence of disintegrative ethnicity' (Mulinge, 2008:63). Primordialist arguments do not account for the timing of an outbreak of violence (Jackson, 2004). For instance why do the conflicts happen when they do and not earlier or later? Why did the Arab -African identities in the 2003 Darfur conflict become such meaningful markers and not during the earlier conflicts in the region? This genetically based idea of ethnicity does not adequately address these sorts of questions. However, despite these deficiencies, the primordialist theory is useful in explaining the emotive dimension of ethnic conflicts and offers insight into the passion-driven behavior of ethnic groups. The power of ethnicity lies in its capacity to arouse passion and commitment (Cornell and Hartman, 1998:151) and once this is wrongly taken advantage of it leads to violent conflicts. The Rwandan Case could easily be a case that demonstrates the primordialist explanation given the clear Hutu/Tutsi dichotomy and the role of ancient grievances and hatreds but while primordial ethnicity played a significant role it did not have an exclusive role in this conflict. Elite manipulation was also a major feature in Rwanda as political elites played a central role and gave expression to these identities by politicizing these differences for as Horowitz (2000) posits, the power of ethnicity is mirrored in the segmented economic and political organizational structures of ethnically divided societies.

\section{Instrumentalism}

The instrumentalist theory sees ethnicity as "neither inherent in human nature nor intrinsically valuable" (Varshney, 2009:282). Ethnicity is perceived as a strategic basis for coalitions that are looking for a larger share of scarce economic or political power and so it is a device for restricting resources to a few individuals (Collier, 2002:26-27). The instrumentalist theory argues that it is rational for parties to organize along ethnic lines depending on the benefit it brings to them. Given that many ethnic conflicts and civil wars happen in relation to opportunities for primary commodity predation (Collier, 2002:26-27), they argue that greed is stronger than grievance as a strong cause of ethnic conflict. Consequently, ethnic conflict arises among rational agents over scarce resources driven by the aims of political leaders for political or economic gains or a deliberate manipulation based on a rational decision to incite or encourage ethnic violence (Chandra 2004). Ethnic conflict is therefore the result of actor's rational activity of widespread interest such as prosperity, power and security. Beyond the explanation of the role of elite manipulation in ethnic wars, the utility of this theory lies also in explaining why some ethnically fragmented societies choose to fight or chose to cooperate rather than fight. This decision, it is argued, depends on the cost and benefit calculations that groups make and so when the cost of cooperation is more than the perceived benefits, ethnic conflicts tend to be unavoidable (Walter, 1997). Instrumentalism also explains why some people take part in ethnic violence even when they are not personally convinced but follow the crowd. In line with this Hardin (1995) argues that ethnic mobilization is a coordination game in which it is rational to cooperate as long as you see others cooperating. Similarly, Collier and Hoeffler (1998) argue that the opportunity costs of participation in a rebellion are low and the benefits in terms of having a share in the loot are often quite substantial. The conflict in the Democratic Republic of Congo is often described mainly as a product of elite manipulation, state failure and illegal exploitation of mineral resources (Autesserre, 2012). The implication of this narrative on resolution of this conflict has been a narrow focus on strategies of state building and reconstruction while paying inadequate attention to the divergence of basic identity which Connor (1994) rightly argues, manifests itself in the 'us-them' syndrome. Moreso, if all behavior in ethnic conflict is explained at the individual level as dominated by desire for individualistic material gains of a few elites, how do the atrocities, of the members of these ethnic groups, like rape, genocide, torture contribute to these gains? It is argued that war rape is sometimes a political instrument to intimidate, humiliate and degrade the 'enemy' as experienced in the case of the Serbs during the Bosnian war whose aim of raping Bosnian Muslim women was to produce little 'Chetniks' (Weitsman, 2008) or the Rwanda case where genocide is described as a political strategy by the elite to buy one groups loyalty by allowing the extermination of the other (Verwimp, 2003:180). While these arguments are plausible, they are incomplete without the emotive content that primordialism emphasizes. Why is it easy to mobilize mass participation effectively along ethnic lines? How do the elite know they can use ethnicity effectively for these gains? These feelings and mass sentiments associated with ethnic identity are not manufactured by elites, they only recognize it and appeal to it (Ruane and Todd, 2004). This is not to suggest that elite manipulation or desire for material gains are not a significant cause of ethnic conflicts but rather that rational 'power-conserving' elite strategies (Fearon, 1995) alone are not sufficient to address the complexity of this phenomenon. 


\section{Constructivism}

The constructivist theory perceives ethnic identity as a socially constructed and fluid entity that can be formed through various means including conquest, colonization or immigration (Wimmer, 2008). Ethnic groups are recognized to be social constructions with 'identifiable origins and histories of expansion and contraction, amalgamation and division' (Posner, 2004:2). They are fluid and originate within a set of social, economic and political processes (Chandra, 2001:7). Constructivists argue that each society has a historically constructed master cleavage and narrative that political entrepreneurs can manipulate (Brass, 2003). Constructivists take identity to be a social category distinguished by rules of membership, characteristics (perceived as typical) or behavior expected in certain circumstances (Fearon and Laitin, 2000:848). They argue that these social categories are not natural, inevitable or unchanging because it is not genes but the internal logic of social discourses that drives identity construction and condition individual's identities with particular groups (Ferejohn, 1991:285). They draw attention to the historical construction and maintenance of exclusive identities by colonial and post-colonial ruling elites for political and social control (Jackson, 2002). The role of language, history, symbols and culture, for constructivists, is significant in instigating and sustaining ethnic rivalry (Kaufman, 2001). Ethnicity is thus flexible, subjective and changes with interethnic interaction and its purpose is to reinforce and perpetuate social differences for specific goals (Jemma, 2006). Ethnic conflict, consequently, is the product of concrete historical processes and these influences in history affect relations between ethnic groups causing hostility between them thus explaining the politicization of ethnic identities (Weir, 2012) caused by a combination of factors, evolving over time and creating a conducive environment for violence. The conflict over Nagorno-Karabakh between Azerbaijan and Armenia that began in the late 1980's is commonly described through constructivist lenses (Kuburas, 2011:43). This is plausible in that it provides an important historical context and explains a central issue in this conflict that is the influence of the Soviet Union and nation-building policies of the $20^{\text {th }}$ Century, which contributed to political and economic grievances among the irredentist minorities in the Caucasus (Kuburas, 2011:44). However, by using maps and border definitions alone to justify territorial claims, analysts ignore the importance of the primordial claims to territory ownership that establishes 'historic legitimacy based on the ancestral tenure' of a given ethnic group (Astourian, 1994:73) thus ignoring the significant role that hatreds, distrust and suspicion played in shaping and sustaining this conflict. As Kaufman (2001:6) rightly observes, 'the most dangerous symbols used in ethnic wars are myths that justify political domination over particular territory, which may have been lost in the past and myths of past atrocities that can be used to justify fears of future genocide'. Similarly, Toft (2003) argues that the primary determinant of ethnic wars is whether state and potential secessionist minorities see their particular claims over territory as divisible or indivisible. Even if ethnic identities are constructed, they could also become internalized and institutionalized in a way that they acquire deep meaning for that group and produce the same emotions that primordial identities would because ethnic groups tend to share a persisting sense of common interests and identity based on these shared historical experiences, valued cultural traits, beliefs, religion, language and shared territory/homeland (Smith, 1993). So while the explanatory power of this theory lies in its ability to draw on multiple dimensions, reflecting both underlying and proximate causes of ethnic conflict and exposing the role of agency within these historical processes showing how the interests of actors, the socio-economic and political environment interact to produce ethnic violence, constructivism does not explain why societies with similar historical processes and structural features commonly associated with conflict do not produce similar conflict histories. For instance, Botswana, described as 'Africa's haven of ethnic peace and harmony' (Mulinge, 2008:61) is a weak state like its neighbor Zimbabwe, heterogenous also and yet has not had the same conflict history that Zimbabwe has had. Again, comprehensive as the constructivist theory may seem, it doesn't account for the timing of the outbreak of conflict (Jackson, 2004). Why do the conflicts erupt at a particular point in these historical processes? Knowing this could help aid prevention. While this theory explains the macro level processes, it is difficult to explain what is happening at the grassroots level and it produces resolution strategies that are too focused on state building while ignoring the underlying animosity.

\section{Conclusion}

Ethnic conflict results in significant loss of lives, denial of basic human rights and severe material destruction and has to be prevented. Understanding its meaning, causes and dynamics of the complex political and social environments within which they thrive is not only important for clarification but also for providing the basis of effective strategies and policies for prevention, intervention and resolution for peace. The major theories of ethnic conflict are each informed by assumptions about the nature of ethnic identity and interethnic relations, they address sensitive and important issues and their utility lies in their ability to address significant aspects of the phenomenon. However, because each of them focuses 
on a one-dimensional perception of ethnic identity, their explanations of the origin of ethnic identity and its role in ethnic conflict appear over simplistic making the theory incapable of comprehensive and meaningful analyses. The implication is that ethnic conflict resolution remains lopsided and in some cases practically impossible because our narrative frame our response and informs the course of action taken to prevent or resolve these conflicts. A narrow focus on a single dimension will continue to produce ineffective intervention or post conflict peace building strategies that are insensitive to other significant factors. A framework that incorporates grievance, greed, weak states, breakdown of security, ethnic geography, intergroup policies, elite politics, unequal economic distribution systems, historical processes and other sociopolitical factors (Brown, 1996:573), could provide a better narrative on a case by case basis.

\section{References}

Astourian, Stephan H. (1994) 'In Search of the Forefathers: National Identity and the Historiography and Politics of Armenian and Azerbaijani Ethnogenesis' in D. V. Schwartz and R. Panossian (ed.) Nationalism and History: The Politics of Nation Building in Post-Soviet Armenia, Azebaijan and Georgia University of Toronto: Centre for Russian and East European Studies pp 41-94

Blagojevic, Bojana (2009) 'Causes of Ethnic Conflict: A Conceptual Framework' Journal of Global Change and Governance, 3(1): 1-25

Brass, P. R. (2003) The Production of Hindu-Muslim Violence in Contemporary India Seattle: University of Washington Press

Bowman, Glen (1994) 'Xenophobia, Fantasy and the Nation: The Logic of Ethnic Violence in Former Yugoslavia', in Victoria Goddard, Joseph Llobera and Chris Shore, (eds.) The Anthroplogy of Europe: Identity and Boundaries in Conflict Washington, D.C. : Berg. pp 143-171

Brown, Michael (1996) 'The Causes and Regional Dimensions of Internal Conflict.' In Brown, M. ed., The International Dimensions of Internal Conflict. Cambridge, MA: MIT Press. pp 571-602

Campbell, David (2007) 'Geopolitics and Visuality: Sighting the Darfur Conflict' Political Geography, 26(4): 357-382

Carment, David (2003) 'Assessing State Failure : Implications for Theory and Policy' Third World Quarterly, 24(3): 407-427

Chandra, Kanchan (2001) 'Cummulative Findings in the Study of Ethnic Politics' APSA-CP, 12(1): 7-25

Chandra, K. (2004) Why Ethnic Parties Succeed Cambridge, UK : Cambridge University Press

Chandra, K (ed.) (2012) Constructivist Theories of Ethnic Conflict Oxford : Oxford University Press Inc.

Collier P. and Hoeffler, A. (1998) 'On the Economic Causes of Civil War' Oxford Economic Papers, 50(4): 563-573

Connor, Walker (1994) Ethnonationalism : The Quest for Understanding Princeton, Princeton University

Cornell, S. and Hartman, D. (1998) Ethnicity and Race : Making identities in a Changing World Pine Forge Press : London

Esteban, Joan, Laura Mayoral and Debraj Ray (2012) 'Ethnicity and Conflict : An Empirical Study' American Economic Review, 102(4) : 1310-1342

Fearon, James D. (1995) 'Rationalist Explanations for War' International Organization, 49(3): 379-414

Fearon, James and Laitin, David (1996) 'Explaining Interethnic Cooperation' American Political Science Review, 90(4): 715-735

Fearon, James and Laitin, David (2003) 'Ethnicity, Insurgency, and Civil War' American Political Science Review, 97(1): 75-90

Ferejohn, John (1991) 'Rationality and Interpretation : Parliamentary Elections in Early Stuart England' in K. Renwick Monroe (ed.) The Economic Approach to Politics : A Critical Reassessment of the Theory of Rational Action New York : Harper Collins pp 279-305

Geertz, Clifford (1973) The Interpretation of Cultures New York : Basic Books

Glazer, Nathan (1986) 'Book Review Understanding Ethnic Conflict : Ethnic Groups in Conflict' Columbia Law Review, 86(2): $427-432$

Hardin, R. (1995) One For All Princeton: Princeton University Press

Holm, J. D and Molutsi, P. P (1992) 'State-Society Relations in Botswana : Beginning Liberalization' in G. Hyden and M. Bratton (eds.) Governance and Politics in Africa Boulder and London : Lynne Rienner pp 75-95

Horowitz, Donald L. (2000) Ethnic Groups in Conflict University of California Press : London, England

Isajiw, Wserolod W. (1993) 'Definitions and Dimensions of Ethnicity: A Theoretical Framework' Statistics Canada \& US Bureau of the Census. Challenges of Measuring and Ethnic World: Science Politics and Reality. Proceedings of the Joint Canada-United States Conference on the Measurement of Ethnicity April 1-3 1992, US Government Printing Office, Washington, DC, 407-427

Ismayilov, Gursel G. (2008) 'Ethnic Conflicts and Their Causes' Khazar Journal of Humanities and Social Sciences, 3(4): 50-63

Jackson, R. (2002) 'Violent Internal Conflict and the African State,' Journal of Contemporary African Studies, 20(1): 29-52

Jackson, R. (2004) 'The Social Construction of Internal War' in Richard Jackson (ed). (Re)Constructing Cultures of Violence and Peace Rodopi: Amsterdam/New York. pp 61-78

Jemma, Hussein (2006) 'Ethnic Conflict as a Global Political Problem : Review of Conceptual and Theoretical Perspectives' Ethiopia OSSREA : Organization for Social Science Research in Eastern and Southern Africa. Accessed 6 March 2014 http://www.ossrea .net/index.php?Option=com_content\&new=article\&id=274

Kaufman, Stuart J. (2001) Modern Hatreds: The Symbolic Politics of Ethnic War Ithaca, NY: Cornell University Press

Kuburas, Melita (2011) 'Ethnic Conflict in Nagomo-Karabakh' Review of European and Russian Affairs, 6(1) : $43-54$

Laitin, D and Sunny, R. G. (1999) 'Armenia and Azerbaijan : Thinking a Way out of Karabakh' Middle East Policy, 7(1) : 145-176

McKay, Al (2011) 'The Study of Modern Intra-State War' E-International Relations Online Accessed 6 March, 2014 http://www.eir.info/2011/2/03/the-study-of-modern-intrastate-war/

Mulinge, Munyae M. (2008) 'Botswana, Africa's Haven of Ethnic Peace and Harmony : Status and Future Prospects' African Journal of Sociology, 4(1) : 61-85 
Nguyen, Mai (2010) 'Causes of Ethnic Conflict : Examining the Role of Religious Diversity and Contagion Effects' Accessed 6 March, 2014 http://www.creighton.edu/fileadmin/user/CCAS/docs/Mai_Nguyen.pdf

Perez, Anthony D. and Hirschman, Charles (2009) 'The Changing Racial and Ethnic Composition of the US Population: Emerging American Identities' Population Development Review, 35(1) : 1-51

Poata-Smith, Evan S. (2013) 'Emergent Identities: The Changing Contours of Indigenous Identities in Aotearoa/New Zealand' in M. Nakata, M. Harris and B. Carlson (eds.) The Politics of Identity: Emerging Indigeneity Sydney: University of Technology Sydney E-Press. pp 24-59

Ruane, Joseph and Todd, Jennifer (2004) 'The Roots of Intense Ethnic Conflict May Not infact be Ethnic : Categories, Communities and Path Dependence' European Journal of Sociology, 45(2) : 1-22

Smith, Anthony D. (1993) 'The Ethnic Sources of Nationalism' in Michael Brown Ed. Ethnic Conflict and International Security Princeton University Press pp 28-39

Toft, Monica D. (2003) The Geography of Ethnic Violence: Identity, Interests, and the Indivisibility of Territory Princeton: Princeton University Press

Turton, D. (1997) 'War and Ethnicity: Global Communications and Local Violence in North-East Africa and Former Yugoslavia' Oxford Development Studies, 25(1): 77-94

Varshney, Ashutosh (2009) Ethnicity and Ethnic Conflict Oxford Handbook Online Accessed 6 March,2014 http://www.oxfordhandbooks. com/view/10.1093/oxfordhb/9780199566020.001.0001/oxfordhb/9780199566020-e-12

Verwimp, Philip (2003) 'The Political Economy of Coffee, Dictatorship and Genocide' European Journal of Political Economy, 19 (2): 161-181

Walter, Little (1997) 'Democratization in Latin America, 1980-95' in David Potter, David Goldblatt, et al. (eds) Democratization United States of America: Blackwell Publishers

Weir, Naomi (2012) 'Primordialism, Constructivism, Instrumentalism in Rwanda' Accessed 6 March, 2014 http://www.academia.edul 1526597/Primordialism_Constructivism_Instrumentalism_and_Rwanda

Weitsman, Patricia A. (2008) 'The Politics of Identity and Sexual Viōence: A Review of Bosnia and Rwanda' Human Rights Quarterly, 30(3): 561-578

Wimmer, Andreas (2008) 'The Making and Unmaking of Ethnic Boundaries: A Multi-level Process Theory' American Journal of Sociology, 113(4): 970-1022 
